\title{
ПОТЕНЦІАЛ ТРЕНІНГОВИХ ТЕХНОЛОГІЙ У ФОРМУВАННІ ПРОФЕСІЙНОЇ СУБ'ЄКТНОСТІ МАЙБУТНІХ ОФІЦЕРІВ ЗБРОЙНИХ СИЛ УКРАЇНИ
}

\author{
Капінус O. C. \\ кандидат педагогічних наук, \\ начальник кафедри морально-психологічного забезпечення діяльності військ \\ Начіональна академія сухопутних військ імені гетьмана Петра Сагайдачного \\ вул. Героїв Майдану, 32, Львів, Украӥна \\ orcid.org/0000-0002-5078-1402 \\ oskap@ukr.net
}

\begin{abstract}
Ключові слова:
тренінг, майбутній офіиер, професійна суб'єктність, військово-професійна підготовка, вищий військовий навчальний заклад.
\end{abstract}

Статтю присвячено теоретичному аналізу потенціалу тренінгових технологій у формуванні професійної суб'єктності майбутніх офіцерів під час навчання у вищих військових навчальних закладах.

3'ясовано, що професійна суб'єктність офіцера є інтегративною професійно важливою якістю, що визначає його життєві та професійні перспективи як суб'єкта військово-професійної діяльності. Сформована професійна суб'єктність є вищою формою регуляції військово-професійної діяльності офіцера та важливою передумовою його особистісно-професійної самоактуалізації, забезпечує узгодженість особистих потреб, здібностей, очікувань відповідно до умов та вимог військово-професійної діяльності. Здійснено узагальнення наявних у сучасному психолого-педагогічному дискурсі поглядів на актуальну потребу впровадження альтернативних підходів до підвищення ефективності військово-професійної підготовки майбутніх офіцерів та формування професійної суб'єктності зокрема.

Встановлено, що суттєвим потенціалом у вирішенні проблеми підвищення ефективності формування професійної суб'єктності майбутніх офіцерів володіють тренінгові технології як альтернатива усталеним підходам до військово-професійної підготовки.

Визначено, що впровадження тренінгових технологій створює дієві передумови до саморозвитку майбутнього офіцера, сприяє інтенсифікації процесу формування професійних знань, умінь, навичок та досвіду їх застосування в реальних ситуаціях військово-професійної діяльності. Крім того, суттєвою перевагою використання тренінгових форм навчання $€$ можливість розкриття наявного потенціалу фахівця, розвиток здібностей та підвищення мотивації, формування готовності до адекватної реакції на зміни під час службової діяльності, підвищення рівня компетентності та спроможності до самостійного ухвалення виваженого управлінського рішення, рефлексії та саморефлексії майбутнього офіцера.

На основі теоретичного аналізу наукової літератури обгрунтовано доцільність впровадження тренінгових технологій у військово-професійну підготовку майбутніх офіцерів у вищих військових навчальних закладах. 


\title{
POTENTIAL OF TRAINING TECHNOLOGIES IN FORMATION OF PROFESSIONAL SUBJECTIVITY OF FUTURE OFFICERS OF THE ARMED FORCES OF UKRAINE
}

\author{
Kapinus O. S. \\ Candidate of Pedagogical Sciences, \\ Head of the Department of Moral and Psychological Support the Activities of the Troops \\ Hetman Petro Sahaidachny National Army Academy \\ Heroiv Maidan str. 32, Lviv, Ukraine \\ orcid.org/0000-0002-5078-1402 \\ oskap@ukr.net
}

Key words:

training, future officer, professional subjectivity, military professional training, higher military educational institution.

\begin{abstract}
The article is devoted to the theoretical analysis of the potential of training technologies in the formation of professional subjectivity of the future officer while studying in higher military educational institutions.

It was found that the professional subjectivity of an officer is an integrative professionally important quality that determines his life and professional prospects as a subject of military-professional activity. The formed professional subjectivity is the highest form of regulation of military-professional activity of the officer and an important precondition of his personal-professional selfactualization, provides coordination of personal needs, abilities, expectations according to conditions and requirements of military-professional activity.

The generalizations of the views available in the modern psychological and pedagogical discourse on the urgent need to introduce alternative approaches to improving the effectiveness of military training of future officers and the formation of professional subjectivity in particular.

It has been established that training technologies as an alternative to established approaches to military training have a significant potential in solving the problem of improving the efficiency of the formation of the professional subjectivity of the future officer.

It is determined that the introduction of training technologies creates effective preconditions for the self-development of the future officer, promotes the intensification of the process of formation of professional knowledge, skills, abilities and experience of their application in real situations of militaryprofessional activity. In addition, a significant advantage of using training forms of training is the ability to unleash the existing potential of the specialist, develop abilities and increase motivation, develop readiness to adequately respond to changes during work, increase competence and ability to make informed management decisions, reflection and self-reflection of the future officer.

Based on the theoretical analysis of the scientific literature, the expediency of introducing training technologies in the military training of future officers in higher military educational institutions is substantiated.
\end{abstract}

Постановка проблеми. В основі організації військово-професійної підготовки майбутніх офіцерів, що здійснюється у вищих військових навчальних закладах (далі - ВВНЗ), здебільшого $\epsilon$ усталені форми організації освітньої діяльності, орієнтовані на суб' єкт-об'єктну взаємодію науково-педагогічного працівника та курсанта. Поряд із тим завдання, які стоять перед офіцерами в сучасних умовах, актуалізують потребу підвищення ефективності виконання ними службово-бойових завдань та зумовлюють необхідність пошуку шляхів інтенсифікації професійної підготовки, впровадження альтернативних форм організації освітньої діяльності у ВВНЗ.

Формування професійної суб'єктності майбутніх офіцерів як особливої інтегративної професійно важливої якості, що визначає їхні життєві та професійні перспективи як суб'єктів військово-професійної діяльності, $є$ одним із пріоритетних завдань системи військової професійної 
освіти, бо саме професійна суб' єктність є вищою формою регуляції військово-професійної діяльності офіцера та важливою передумовою його особистісно-професійної самоактуалізації, забезпечує узгодженість особистих потреб, здібностей, очікувань відповідно до умов та вимог військово-професійної діяльності у військових частинах, гармонійно поєднується з позитивною Я-концепцією офіцера, професійною зрілістю, відповідальним ставленням до військово-професійної діяльності та ії результатів, адекватною самооцінкою, саморефлексією та активністю в самореалізації у професії офіцера.

Питання навчання і виховання майбутніх офіцерів, формування їх професійної суб'єктності досліджували вітчизняні педагоги та психологи: I. Бех, Г. Васянович, С. Гончаренко, М. Данилов, М. Д'яченко, А. Дьомін, Л. Занков, Л. Кандибович, Л. Карамушка, Н. Коломінський, Г. Костюк, В. Моляко, М. Нещадим, О. Романовський, В. Ягупов та ін., зарубіжні учені: К. Арджіріс, Г. Емерсон, Ч. Бернард, М. Вебер, П. Друкер, Д. Макгрегор, А. Маслоу, Е. Мейо, Ф. Тейлор, А. Файоль, М. Фоллет та ін. Використання тренінгів у професійній підготовці фахівців було в спектрі наукового пошуку широкого кола дослідників, серед яких: А. Алексюк, Л. Бондарєва, О. Свтух, С. Занюк, В. Зайчук, I. Мельничук, А. Нісімчук, О. Падалка, І. Підласий, О. Пометун, Г. Сазоненко, С. Іванішева та ін.

Теоретичне осмислення актуальної проблеми пошуку шляхів підвищення ефективності формування професійної суб'єктності майбутніх офіцерів із використанням потенціалу тренінгових технологій дає змогу дійти висновку, що зумовлене питання в сучасному науковому дискурсі має різнопланову інтерпретацію, а складність проблеми зумовлює iї грунтовний аналіз.

Мета статті. Головною метою статті $є$ теоретичне обгрунтування потенціалу впровадження та використання тренінгових технологій у формуванні професійної суб'єктності майбутніх офіцерів під час навчання у вищих військових навчальних закладах, адже зумовлена проблема ще не має повного теоретичного та методичного обгрунтування в педагогічній науці.

Виклад основного матеріалу дослідження. Аналіз ефективності виконання офіцерським складом Збройних сил України службово-бойових завдань протягом останніх років вказує на нагальну потребу пошуку альтернативних підходів до формування в майбутніх офіцерів під час навчання у вищих військових навчальних закладах якостей, що забезпечать змогу адекватно реагувати на ситуації з нормативною невизначеністю, усвідомлено проявляти ініціативу, брати на себе повної відповідальності за ухвалені управлінські рішення. Крім того, у професійній діяльності офіцера має місце тенденція до зростання питомої ваги та кількості ситуацій, що потребують переходу від рольових відносин до особистісно-смислових, що зумовлює необхідність належного рівня сформованості професійної суб'єктності офіцера - якості, що визначає його тенденцію $\mathrm{i}$ здатність до ініціювання та регулювання професійної активності відповідно до внутрішніх критеріїв ефективності та доцільності, сприяє позитивному самосприйняттю та самовідношенню, а також самодетермінації та саморегуляції у професійній діяльності [1].

3 урахуванням поглядів I. Сиромятникова, на думку якого професійна діяльність офіцера дуже специфічна через інтеграцію в ній правових, соціальних, психологічних, етичних та інших аспектів, які пов'язані з необхідністю прийняття ними самостійних і обгрунтованих рішень, які часто зачіпають долі і життя інших людей, важливим завданням $\epsilon$ формування в офіцерів адекватного розуміння необхідності та можливостей свого суб'єктного внеску в ту чи іншу зміну якісних параметрів об'єкта діяльності [2, с. 4].

Одним 3 оптимальних варіантів вирішення проблеми формування професійної суб'єктності майбутніх офіцерів у процесі професійної підготовки є тренінгові технології, які «стають дедалі популярнішою формою професійної підготовки студентів різних спеціальностей» [3, с. 114], створюючи додаткові умови для самопізнання та самовдосконалення майбутнього офіцера на основі суб'єкт-суб' єктного підходу та забезпечення оптимальних умов становлення його активним суб'єктом освітнього процесу.

Дефініція «тренінг» у сучасній психолого-педагогічній літературі трактується досить широко. Так, К. Фопель під тренінгом розуміє «такі види навчання, об'єктом впливу якого є якості, властивості, вміння, здібності й установки, які відображаються у спілкуванні» [4, с. 7], тоді як В. Федорчук розглядає тренінг як «інтенсивний курс навчання, який поєднує короткі теоретичні заняття 3 практичною частиною використання навичок за короткий строк» [5, с. 4], зазначаючи при цьому, що саме тренінг $€$ «найперспективнішим методом психолого-педагогічної підготовки фахівців різних галузей» [5, с. 10].

Загалом більшість дослідників під тренінгом розуміють:

- спеціальну форму організації діяльності, що переслідує конкретні і прогнозовані цілі, котрі можуть бути досягнуті у порівняно короткий термін;

- спосіб навчання учасників і учасниць та розвиток у них необхідних здібностей та якостей, що дають змогу досягти успіху в певному виді діяльності; 
- інтенсивне навчання, що досягається спеціальними інтерактивними методами [6, с. 5].

3 огляду на особливості військово-професійної підготовки майбутніх офіцерів у трактуванні дефініції «тренінг» ми погоджуємось із його визначенням, запропонованим авторами навчально-методичного посібника «Тренінгові технології у навчанні та вихованні військовослужбовців»: «Тренінг - це метод активного навчання, скерований на розвиток знань, умінь, навичок і соціальних установок, під час якого людина переглядає власні цінності та пріоритети, коригує, удосконалює та розвиває певні якості та властивості своєї особистості, вибирає для себе такі форми та методи поведінки, які відповідають саме їі життєвій ситуації та індивідуальності» [7, с. 16].

Погоджуємось із твердженням укладачів Тлумачного словника української мови, на думку яких тренінг є «запланованим процесом модифікації (зміни) відношення, знання чи поведінкових навичок того, хто навчається, через набуття навчального досвіду 3 тим, щоб досягти ефективного виконання в одному виді діяльності, або в певній галузі» [8], і поділяємо погляди К. Фоппеля, який аргументовано доводить, що об'єктом впливу під час тренінгу є «якості, властивості, вміння, здібності й установки» [4, с. 7] особистості та майбутнього офіцера зокрема.

Крім того, визначальною особливістю тренінгів $є$ наявний потенціал до здійснення впливу на особистість, результатом чого є зростання самооцінки, зміна стратегії поведінки, зникнення бар'єрів у міжособистісному спілкуванні [9, с. 97-101], а результати участі в тренінгу характеризуються міцністю, глибиною і генералізованістю (можливістю застосування в широкому діапазоні професійних ситуацій) [10, с. 32-33].

3 огляду на особливості підготовки майбутніх офіцерів у ВВН3, вимог до професії військовослужбовця та офіцера зокрема, зумовленої потреби формування професійної суб'єктності майбутнього офіцера, ми виокремлюємо низку вимог до організації та проведення тренінгів:

- суб'єктна спрямованість підготовки та проведення тренінгів;

- активна позиція учасників тренінгу, обов'язкове залучення кожного курсанта до практичної діяльності та вироблення варіанту вирішення навчального завдання;

- моделювання тренінгових завдань та умов їх виконання, максимально наближених до реальних, 3 урахуванням особливостей і умов виконання завдань офіцером у різних умовах;

- формування психологічної готовності та психологічної стійкості майбутніх офіцерів до виконання службових завдань, зокрема й бойових;

- формування навичок поведінки в нестандартних та нетипових ситуаціях професійної діяльності;
- використання максимального спектру технологій, прийомів та технік під час підготовки та проведення тренінгів;

- визнання необхідності набуття досвіду ухвалення управлінського рішення пріоритетним завданням участі курсанта у тренінгу;

- суб'єкт-суб'єктна взаємодія учасників тренінгу;

- обов'язковий аналіз отриманих результатів у складі групи та персонально кожним учасником.

Основними техніками, використання яких вбачається найбільш доречним у тренінговій роботі 3 майбутніми офіцерами, є групова дискусія, «Мозковий штурм», аналіз ситуаційних вправ, аналіз критичних випадків, рольова гра та метод «кейсів» (проблемних ситуацій).

Використання методу групової дискусії сприяє виробленню вмінь спільної діяльності курсантів у військових командах, швидкого та оптимального вирішення завдань. Крім того, групова дискусія $\epsilon$ методом активного навчання та стимуляції групових процесів, підвищення ефективності ухвалення спільних рішень та згуртування команди. Використання «Мозкового штурму» дає змогу забезпечити набуття вмінь майбутніми офіцерами генерування ідей, їх формулювання, обговорення та оцінювання.

Участь курсантів у проведенні аналізу ситуаційних вправ сприяє набуттю досвіду вирішення проблемних ситуацій військово-професійної діяльності. Проведення тренінгу на основі методу аналізу критичних випадків передбачає наявність в учасників певних базових знань за темою обговорення, що забезпечує наведення курсантами прикладів та формулювання ідей під час виконання вправи.

Проведення рольової гри як засобу розширення досвіду учасників тренінгу шляхом створення нетипової та нешаблонної ситуації, вироблення уміння прийняття позиції (ролі) когось 3 учасників із подальшим пошуком способів тї вирішення передбачає максимальне їі наближення до реального життя та детальний опис усіх аспектів ситуації, що розглядається.

Використання методу «кейсів» (проблемних ситуацій) створює дієві передумови опанування майбутніми офіцерами моделей успішної поведінки в реальних ситуаціях військово-професійної діяльності. Крім того, активна взаємодія учасників тренінгу та комунікативна природа методу «кейсів» уможливлює оперативну оцінку отриманих результатів та запропонованих рішень.

Загалом визначальними перевагами використання тренінгових технологій у процесі формування професійної суб'єктності майбутнього офіцера, на відміну від традиційних форм організації освітньої діяльності у вищих військових навчальних закладах, $є$ : 
- підвищення результативності опанування теоретичних знань, формування вмінь та навичок їх використання в ситуаціях, максимально наближених до притаманних професії;

- набуття вмінь діяти активно та наполегливо в досягненні цілей;

- розширення діапазону моделей професійної діяльності в різних умовах виконання службово-бойових завдань та практична перевірка їх ефективності в середовищі, максимально наближеному до реального;

- розвиток нестандартного мислення та вміння відстоювати власну точку зору щодо варіантів вирішення актуальної професійної проблеми;

- формування готовності курсанта брати на себе відповідальність за результати діяльності та ухвалених рішень;

- можливість перевірки рівня професійної готовності майбутнього офіцера до виконання завдань за призначенням.

Використання тренінгових занять у військово-професійній підготовці майбутніх офіцерів та формуванні професійної суб'єктності зокрема сприяє виробленню індивідуального стилю поведінки, суттєво розширює діапазон моделей поведінки в імовірних проблемних ситуаціях, забезпечує інтенсифікацію розвитку професійного мислення та має наслідком сприйняття майбутнім офіцером себе повноцінним суб'єктом військово-професійної діяльності.
Висновки і перспективи подальших розробок. Запровадження тренінгових технологій у процес військово-професійної підготовки майбутніх офіцерів сприяє набуттю вмінь самостійного визначення мети професійної діяльності майбутніми офіцерами як і1і суб'єктами та стійкому прагненню іiі досягнення, підвищенню рівня мотивації, формуванню позитивного ставлення до управлінської діяльності, опануванню практичних механізмів i технік ефективного планування, контролю професійної діяльності, розвитку вмінь рефлексії отриманих результатів.

Застосування тренінгів створює дієві передумови досягнення пріоритетної цілі військово-професійної підготовки - формування професійної суб'єктності майбутнього офіцера через наявний потенціал до забезпечення оптимальних умов самопізнання та самовиховання майбутнього офіцера, розкриття індивідуальних особливостей та розвиток особистісних та професійних якостей курсанта, формування професійно орієнтованих умінь та практичних навичок, вироблення індивідуального стилю управлінської діяльності та суб'єктної поведінки майбутнього офіцера.

Подальші перспективи дослідження полягають у розробленні методики формування професійної суб' єктності майбутніх офіцерів із використанням потенціалу тренінгових технологій.

\section{Література}

1. Ягупов В.В. Формирование и развитие профессиональной субъектности офицеров. Известия Российской академии образования. 2013. № 1. С. 74-83.

2. Сыромятников И.В. Психология профессиональной субъектности офицеров Вооруженных сил Российской Федерации : автореф. дис. ... д-ра психол. наук : 19.00.03. Москва, 2007. 48 с.

3. Мельничук І.М., Мельничук С.Ю. Загальна характеристика основних цілей використання навчальних тренінгів у професійній підготовці майбутніх фахівців. Вісник Черкаського університету. Серія «Педагогічні науки». 2016. № 9. С. 113-117.

4. Фопель К. Технология ведения тренинга. Теория и практика. Москва, 2007. 267 с.

5. Федорчук В.М. Соціально-психологічний тренінг «Розвиток комунікативної компетенції викладача» : навч.-методичний посібник. Кам'янець-Подільський, 2004. 240 с.

6. Технологія тренінгу / за заг. ред. С.Д. Максименко. Київ, 2008. 112 с.

7. Тренінгові технології у навчанні та вихованні військовослужбовців : навч.-метод. посібник / Т. Грицевич, О. Капінус, Т. Мацевко та ін. Львів : НАСВ, 2019. 405 с.

8. Тлумачний словник української мови: понад 12500 статей (близько 40000 слів) / за ред. В.С. Калачника. 2-ге вид., випр. і доп. Харків : Прапор, 2005. 992 с.

9. Мельничук I.М., Чорній В.Я. Психолого-педагогічний тренінг як активний засіб підвищення комунікативної компетентності майбутнього фахівця фінансово-економічної сфери. Педагогічний альманах : збірник наук. праць. 2010. Вип. 6. С. 97-101.

10. Семенчук Ю.О. Використання технологій інтерактивного навчання студентів-економістів термінологічної лексики. Науково-методичний журнал. 2010. № 1. С. 31-35.

\section{References}

1. Iahupov, V.V. (2013). Formyrovanye y razvytye professyonalnoi subjektnosty ofytserov [Formation and development of professional subjectivity of officers]. Yzvestyia Rossyiskoi akademyy obrazovanyia - Bulletin of the Russian Academy of Education, 1, 74-83 [in Russian]. 
2. Syromiatnykov, Y.V. (2007). Psykholohyia professyonalnoi subjektnosty ofytserov Vooruzhennykh syl Rossyiskoi Federatsyy [Psychology of professional subjectivity of officers of the Armed Forces of the Russian Federation]. Extended abstract of Doctor's thesis. Moskva [in Russian].

3. Melnychuk, I.M. \& Melnychuk, S.Yu. (2016). Zahalna kharakterystyka osnovnykh tsilei vykorystannia navchalnykh treninhiv u profesiinii pidhotovtsi maibutnikh fakhivtsiv [General characteristics of the main objectives of the use of training in the training of future professionals]. Visnyk Cherkaskoho universytetu. Seriia «Pedahohichni nauky» - Bulletin of Cherkasy University. Series «Pedagogical Sciences», 9, 113-117 [in Ukrainian].

4. Fopel, K. (2007). Tekhnolohyia vedenyia trenynha. Training technology. [Theory and practice Teoryia y praktyka]. Moskva [in Russian].

5. Fedorchuk, V.M. (2004). Sotsialno-psykholohichnyi treninh "Rozvytok komunikatyvnoi kompetentsii vykladacha" [Social and psychological training "Development of communal competence vicladach"]. Kamianets-Podilskyi [in Ukrainian].

6. Maksymenko, S.D. (2008). Tekhnolohiia treninhu [Training technology]. Kyiv [in Ukrainian].

7. Hrytsevych, T., Kapinus, O. \& Matsevko, T. (2019). Treninhovi tekhnolohii u navchanni ta vykhovanni viiskovosluzhbovtsiv [Training technologies in training and education of servicemen]. Lviv: NASV [in Ukrainian].

8. Kalachnyk, V.S. (2005). Tlumachnyi slovnyk ukrainskoi movy: ponad 12500 statei (blyzko 40000 sliv) [Explanatory dictionary of the Ukrainian language: more than 12,500 articles (about 40,000 words)]. Kharkiv: Prapor [in Ukrainian].

9. Melnychuk, I.M. \& Chornii, V.Ia. (2010). Psykholoho-pedahohichnyi treninh yak aktyvnyi zasib pidvyshchennia komunikatyvnoi kompetentnosti maibutnoho fakhivtsia finansovo-ekonomichnoi sfery [Psychological and pedagogical training as an active means of increasing the communicative competence of the future specialist in the financial and economic sphere]. Pedahohichnyi almanakh-Pedagogical almanac, 6, 97-101 [in Ukrainian].

10. Semenchuk, Yu.O. (2010). Vykorystannia tekhnolohii interaktyvnoho navchannia studentiv-ekonomistiv terminolohichnoi leksyky [Use of technologies of interactive teaching of students-economists of terminological vocabulary]. Naukovo-metodychnyi zhurnal - Scientific and methodical journal, 1, 31-35 [in Ukrainian]. 